\title{
Reconstruction of Value Added Tax Incentive Policy on Purchasing Vessels in Terms of The Principle of Ease of Administration in Developing the National Shipping Industry
}

\author{
Iwan Amisi ${ }^{1}$, Haula Rosdiana ${ }^{2}$ \\ iwan.amisi@yahoo.co.id ${ }^{1}$, haula.rosdiana2013@gmail.com²
}

Faculty of Administrative Sciences, University of Indonesia, Depok ${ }^{1}$ Faculty of Administrative Sciences, University of Indonesia, Depok ${ }^{2}$

\begin{abstract}
The VAT incentive policy on vessel purchases by the National Commercial Shipping Company has been amended several times from the original Government Borne VAT (DTP), VAT Exemption Certificate (SKB) and the latest being VAT is not collected (SKTD). This study uses a qualitative method aimed at reconstructing VAT incentive policies on vessel purchases by National Shipping and analyzing the implications of changing VAT administration policies for shipping industry players on vessel purchases based on the principle of ease of administration. The results showed that the change in the VAT incentive policy on the purchase of ships to VAT was not collected, in accordance with the neutral VAT characteristics. The results of the principle of ease of administration analysis show that the change in the implementation of the VAT incentive administration policy does not only burden national shipping companies but also the Government (Directorate General of Taxes).
\end{abstract}

Keywords: VAT incentives, Ship Purchase, Neutral, Ease of Administration

\section{Introduction}

The dominance that Indonesia's territory consists mostly of water, is an indisputable fact, so the existence of the National Shipping Industry is one of the industries that is very strategic and needs to be developed. The shipping industry is needed not only to connect (connectivity) existing islands, but also to support Indonesia's economic growth. The following are reasons why the shipping industry needs to be given priority [1]:

a. Increasing Indonesia's competitiveness in the global market because almost all commodities for international trade are transported using maritime transportation facilities and infrastructure, and

b. Balancing regional development (between Eastern Indonesia and Western Regions) for the unity of Indonesia, because remote and underdeveloped regions (the majority of which are located in Eastern Indonesia are rich in natural resources) need access to markets and services, which can often only be done by transportation maritime. 
Various efforts have been made by the Indonesian government to empower the national shipping industry while at the same time upholding the country's sovereignty in the maritime sector. One of the phenomenal policies, of course, is the issuance of Presidential Instruction (Inpres) No. 5 of 2005 concerning Shipping Industry Empowerment. In the Inpres, for the first time the government implemented The Cabotage Principle consistently. The implementation of the cabotage principle was later strengthened by the inclusion of these principles in Law number 17 of 2008 concerning Shipping. The Cabotage Principle is a domestic transportation activity carried out by a national sea transportation company using Indonesian-flagged vessels and operated by Indonesian crewmen. The application of this principle is aimed at protecting the sovereignty of the state and supporting the realization of the archipelago's insights and providing the widest possible business opportunity for national sea transport companies [2].

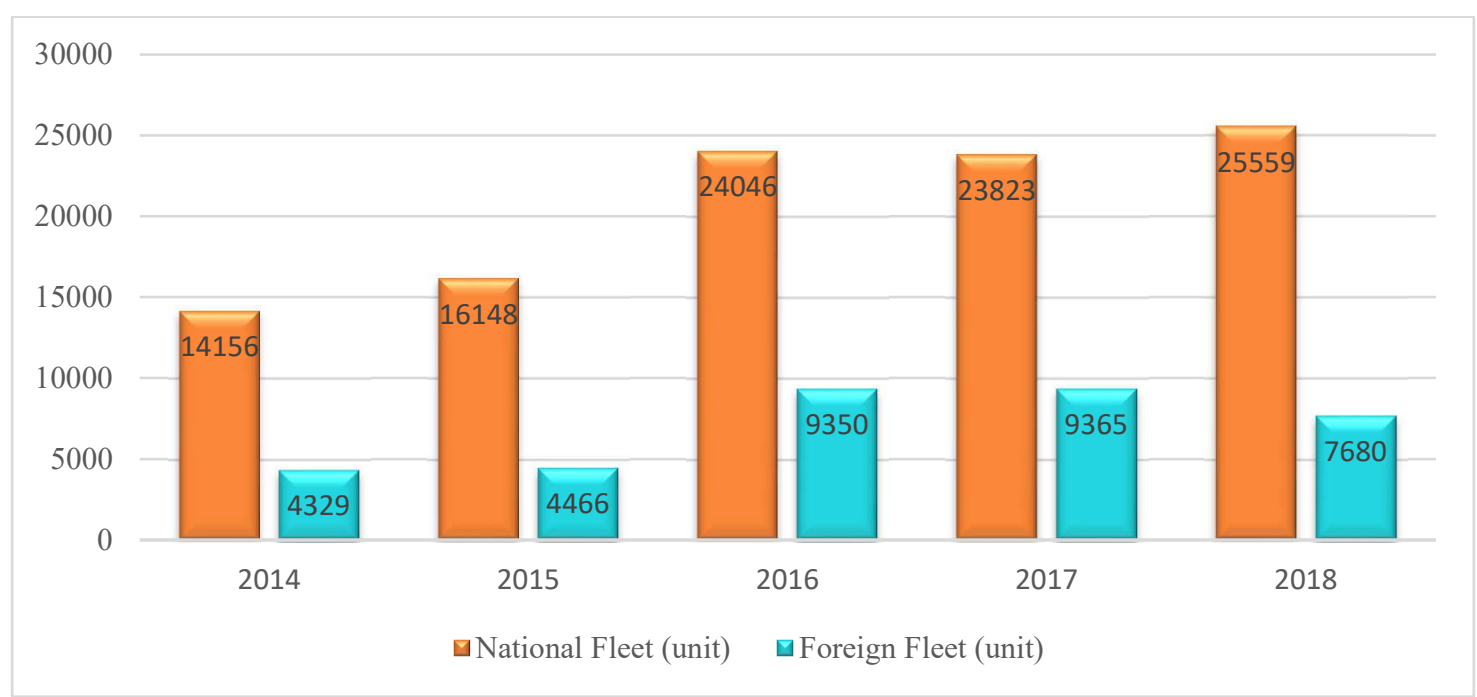

Fig.1. [3] Number of National and Foreign Shipping Fleets in Indonesia

Based on Figure 1 above, it is known that the Indonesian shipping fleet consists of national and foreign fleets, from 2014 to 2018 the number of national fleets has increased every year. The government policy that encourages the increase in the number of national fleets is the application of The Cabotage Principle.

The growth of the shipping industry in these years was also triggered by the existence of a government mandate which one of the programs is the sea highway which was held on November 4, 2015 with 2 routes. Then in 2016 it will increase to 6 routes, in 2017 there will be 13 routes and 18 routes in 2018. Likewise, livestock vessels will continue to grow. Originally there were only 1 (one) livestock vessels in 2015 and an increase of 6 vessels in 2018. Initially the transportation of animals was carried by cargo ships and now it is specially transported by sea-specific cattle toll boats [4].

Various efforts have actually been made by the Indonesian government to improve the national shipping industry, but the Indonesian Shipping Company Association (Indonesian National 
Shipowner Social Assistance / INSA) assesses the government has not shown a commitment to implementing Law No. 17 of 2008 considering the tax and cost of ship components is still very burdensome to the national shipping industry. So far, the tax sector has contributed 17 percent to the swelling of ship production costs. INSA considers that the government is not consistent in applying the cabotage principle because it has not provided an ideal incentive for national customers in the shipping sector.

INSA in the National Shipping Dynamics and Challenges paper presented at the Conference at ICE BSD Serpong, 2-4 March 2017 stated that INSA encourages equal treatment both in fiscal and monetary terms to improve the competitiveness of the national shipping industry. As regulated in Article 57 paragraph (1) letter a of Law No. 17 of 2008 concerning shipping, referred to as "granting facilities in the field of financing and taxation" [5].

Tax incentives are a form of taxation facilities provided by the government to certain taxpayers in the form of reduced tax rates that aim to reduce the amount of tax burden that must be paid, including (1) exemption from taxation, (2) tax deferral, (3) reducing the tax base and (4) reducing the tax rate [6].

One of the government's efforts to support the shipping industry $d$ is to provide tax facilities in the form of tax exemptions, in the form of an Value Added Tax not levied on imports and delivery of ships and spare parts, as well as shipping safety and human safety equipment. VAT incentive policies on imports and ship handover have been amended several times. First, the governmentborne PPN facility-building policy (DTP) was established through a Presidential Decree in 1996, the second PPN was released determined through Government Regulation 2000 as the implementation of Law No. 18 of 2000, the three VATs are not collected through Government Regulation No. 69 of 2015 as the implementation of Law No. 42 of 2009.

The implementation of the policies stipulated in the law will ultimately only work if there is a tax administration [7]. The change of VAT incentive administration policy on ship purchases by the National Shipping Industry since the enactment of VAT in Indonesia in 1985 until now is interesting to do an academic study in terms of the principle of ease of administration so that the VAT incentive administration policy is in accordance with the purpose of providing tax facilities to the Shipping Industry in Indonesia .

Based on these thoughts, it is important to review the Government's Reconstruction Policy Reconstruction of Value Added Tax incentives for vessel purchases at the National Shipping Company.

\section{Research Method}

In analyzing and discussing the problems raised on the subject matter, the author uses qualitative methods, studies documentation, literature and relevant data from the Ministry of Transportation and the Directorate General of Taxes (DGT). According to Creswell Qualitative research is defined as a process of inquiry to understand social problems or human problems, based on the creation of a complete holistic picture formed with words, reporting the views of informants in detail, and arranged in a natural setting [8]. 
The qualitative research is Research departs from naturalistic inquiry whose findings are not obtained from statistical calculation procedures. Qualitative methods can be used to uncover and understand something behind a phenomenon that is not yet known [9].

This research was conducted using a qualitative approach because it is seen from the basic assumptions of the basic nature of science (epistemology) that this research is idiographic or holistically holistic. Apart from that, the basic assumption of the research objective (axiology) is to find meaning in understanding the government's Value Added Tax policy.

In this study, researchers used a qualitative approach because researchers wanted to bring a deeper explanation of the policies that had been implemented. Qualitative research focuses more on the "process" aspect than the "outcome". This is due to the relationship of the parts studied will be much clearer if observed in the process [10].

The choice of a qualitative approach is intended so that this research can provide a thorough explanation and understanding of the process or utilization of fiscal incentive policies for the shipping industry.

\section{Discusion}

The number of national shipping fleets experienced significant growth in the period 2014 - 2018. In 2014, the number of shipping fleets in Indonesia was 14,156, but in 2018 it had increased to 25,559 ships or an increase of $81 \%$. However, the shipping fleets in Indonesia are mostly only ships with a small carrying capacity of around 500 TEUs, so they cannot compete with foreign vessels that have a large carrying capacity (10,000 TEUs). In order to further enhance the competitiveness of these foreign shipping companies, the government continues to encourage the growth of the national shipping fleet by providing tax facilitation in the form of VAT incentives. The provision of these facilities aims to further support the success of high-priority sectors of economic activity on a national scale, encourage the development of the business world, and increase competitiveness, support national resilience and facilitate national development.

The provision of fiscal incentives for certain goods and services is well known in the practice of applying VAT internationally. In Indonesia, the provision of fiscal incentives so far has been regulated through Article 16B of the VAT Act, namely by granting VAT facilities "free" or "exempt" from VAT imposition. If VAT is "not collected" for an item or service, the Input Tax paid on the acquisition or production process of the goods or service can be credited, while the Input Tax paid on the acquisition or the process of producing goods or services "exempted" from the imposition of VAT cannot be credited. In the future regulation of the VAT Bill, the 'waived' VAT facility is still maintained, while the VAT facility 'not collected' is reclassified to be subject to VAT at a rate of $0 \%$ (zero rating) with the aim of simplification.

Since it was first enacted on April 1, 1985, the provision of taxation facilities in the form of VAT incentives for vessel purchases by national shipping companies has several times experienced changes in VAT administration as can be seen in the following table. 
Table 1. Comparison of PPN incentive administration policies for the purchase of Ships in 1994, 2000 and 2009

\begin{tabular}{|c|c|c|}
\hline VAT Law No. 11 of 1994 [15] & VAT Law No. 18 of 2000 [16] & $\begin{array}{l}\text { VAT Law No. } 42 \text { of } 2009 \\
{[17]}\end{array}$ \\
\hline $\begin{array}{l}\text { Presidential Decree No. } 4 \text { of } 1996 \\
\text { [18] }\end{array}$ & $\begin{array}{l}\text { Government Regulation No. } 146 \text { of } 2000 \\
\text { [19] }\end{array}$ & $\begin{array}{l}\text { Goverment Regulation No. } \\
69 \text { of } 2015 \text { [20] }\end{array}$ \\
\hline \multirow[t]{3}{*}{$\begin{array}{l}\text { Minister of Finance Decree no. } \\
326 \text { / KMK.04 / } 1996 \text { [21] } \\
\text { Article 9 states: } \\
\text { Businessmen who import and / or } \\
\text { deliver Taxable Goods, are } \\
\text { obliged to stamp "VAT borne by } \\
\text { the Government (DTP) ex } \\
\text { Presidential Decree Number } 4 \text { of } \\
\text { 1996" on each sheet of the Tax } \\
\text { Invoice or PIUD that is issued. }\end{array}$} & $\begin{array}{l}\text { Minister of Finance Decree no. } 10 / \\
\text { KMK.04 / 2001 [22] } \\
\text { Article } 3 \text { paragraph (3) and Article } 4 \\
\text { paragraph (5) states: National shipping } \\
\text { which imports / receives shipments } \\
\text { surrendered from the imposition of VAT } \\
\text { must have a Examption Certificate (SKB) } \\
\text { issued by the DGT. }\end{array}$ & $\begin{array}{l}\text { Minister of Finance } \\
\text { Regulation no. 193 / } \\
\text { PMK.04 / } 2015 \text { [23] } \\
\text { Article } 6 \text { paragraph (5) } \\
\text { states: } \\
\text { Taxpayers who import } \\
\text { ships / accept delivery of } \\
\text { ships must have a } \\
\text { Certificate of VAT Not } \\
\text { Collected (SKTD PPN) } \\
\text { that is valid until } \\
\text { December } 31 \text { of the year } \\
\text { concerned. }\end{array}$ \\
\hline & $\begin{array}{l}\text { Article } 3 \text { paragraph (5) and Article } 4 \\
\text { paragraph (6) states: } \\
\text { Application for obtaining VAT SKB on } \\
\text { Ship import / acquisition attached with } \\
\text { import documents / purchase documents } \\
\text { and documents relating to the operation of } \\
\text { national commercial shipping } \\
\text { Article } 3 \text { paragraph (7) states: National } \\
\text { Commercial Service Companies that } \\
\text { import ships must make a Tax Payment } \\
\text { Letter of the released VAT }\end{array}$ & $\begin{array}{l}\text { Article } 7 \text { paragraph (2) } \\
\text { states: } \\
\text { To obtain the SKTD as } \\
\text { referred to in Article } 6 \\
\text { paragraph (5), the } \\
\text { Taxpayer must submit an } \\
\text { application for the SKTD } \\
\text { to the Director General of } \\
\text { Tax c.q. Head of the Tax } \\
\text { Service Office where the } \\
\text { Taxpayer is registered by } \\
\text { attaching the RKIP } \\
\text { (planned import and } \\
\text { acquisition requirements) }\end{array}$ \\
\hline & $\begin{array}{l}\text { Article } 4 \text { paragraph (9) states : the } \\
\text { company delivering the ship is obliged to } \\
\text { issue a Tax Invoice for which the VAT is } \\
\text { waived }\end{array}$ & $\begin{array}{l}\text { Article } 7 \text { paragraph (3) } \\
\text { states: } \\
\text { On the SKTD request as } \\
\text { referred to in paragraph } \\
\text { (2), the Head of the Tax } \\
\text { Service Office on behalf of } \\
\text { the Director General of } \\
\text { Taxes can issue the SKTD } \\
\text { no later than } 5 \text { (five) } \\
\text { working days after the } \\
\text { SKTD request is received } \\
\text { in full. }\end{array}$ \\
\hline
\end{tabular}




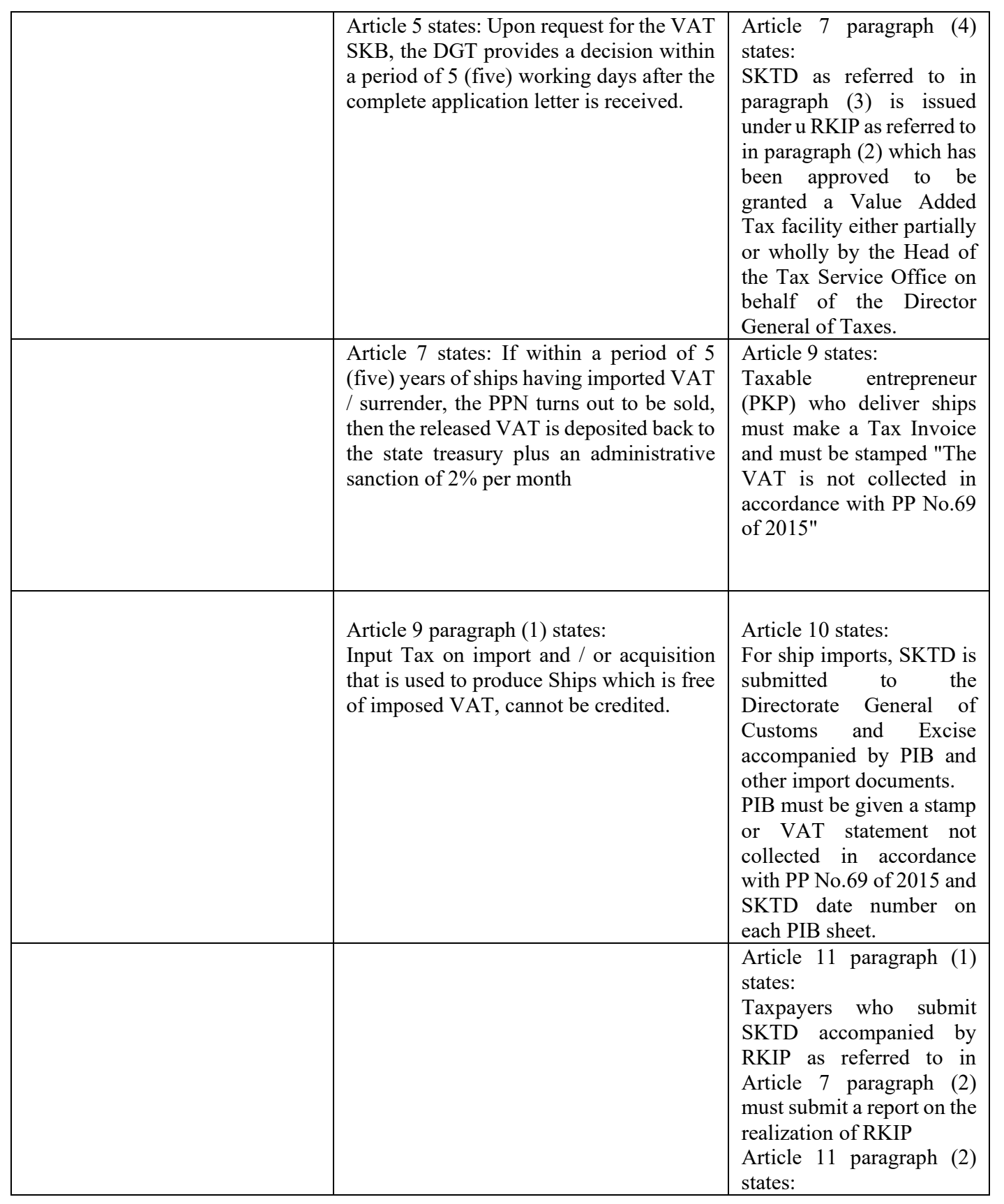




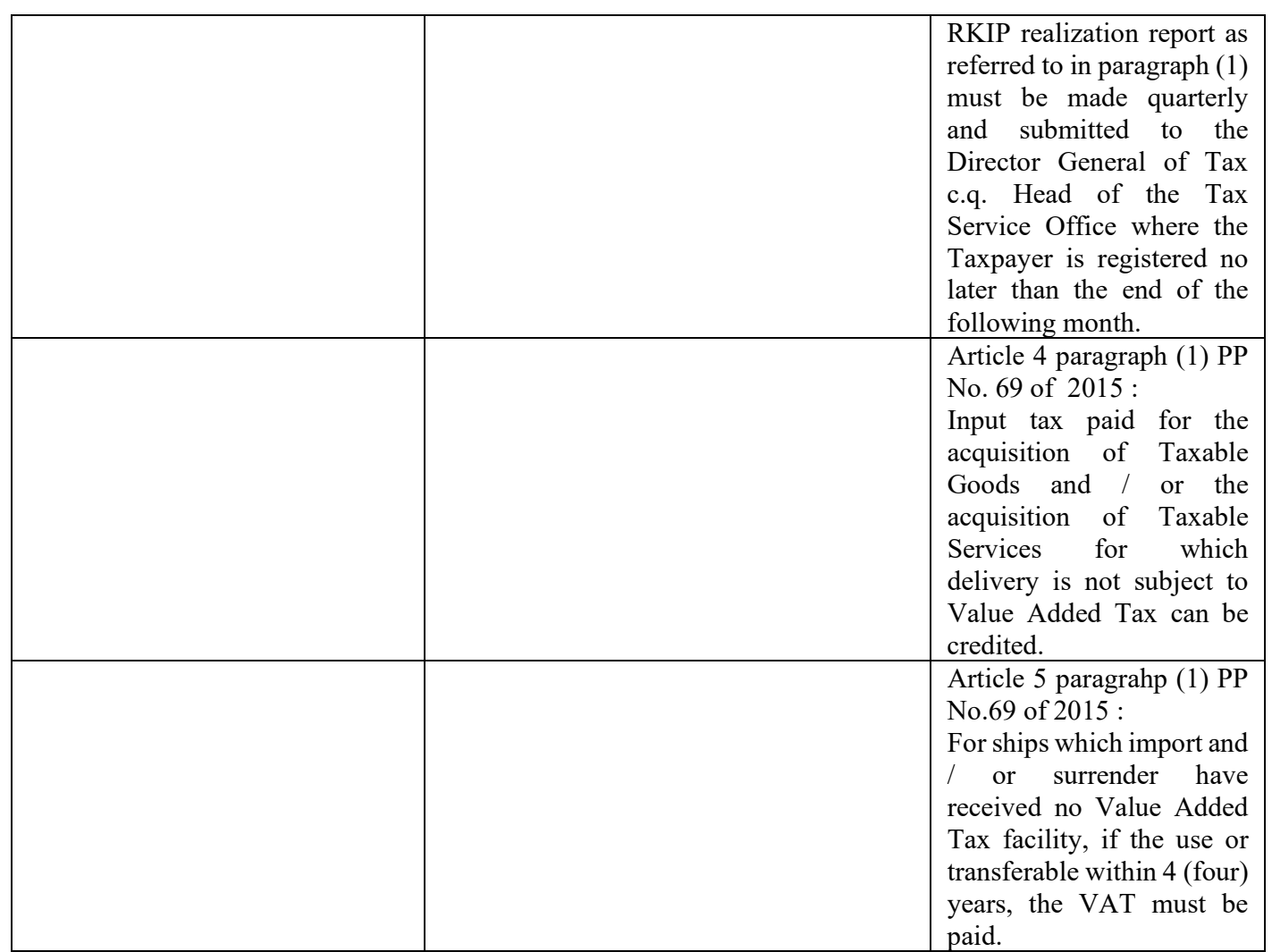

The following is an explanation of each PPN incentive administration that applies in the purchase of ships by national commercial shipping companies.

a. VAT borne by the Government (PPN DTP)

The provision of tax incentives in the form of VAT on ship imports / delivery of ships on National Shipping has been put into effect by the government through Minister of Finance Decree Number 326 / KMK 04/1996. At that time, the government was still imposing a government-borne VAT (DTP) policy on ship imports on the grounds that the number of vessels in Indonesia was still limited while demand for ships continued to increase. To obtain government-borne VAT facilities, the Directorate General of Customs and Excise will affix a "Government Borne" stamp on the Import Notification for Use (PIUD) sheet, when National Shipping is importing ships. Meanwhile, to obtain the Government Borne VAT facility for the acquisition of ships from within the country (local purchases), the seller only needs to affix a "government borne" stamp on each sheet of the Tax Invoice accompanied by documents of the Shipping Business Permit (SIUPP).

b. VAT Exemption Certificate (SKB PPN)

In 2001, through Government Regulation number 146 of 2000 as the latest amended by Government Regulation number 38 of 2003 and Minister of Finance Decree number 10 / KMK 
04/2001, the government issued a replacement policy for KMK 326 / KMK.04 / 1996 where to obtain tax facilities in the form of PPN incentives are exempt, National Sailing must have an exemption Certificate (SKB) from the Directorate General of tax cq the tax office where the National Sailing is registered which must be completed with documents, namely Photocopy of Taxpayer Identification Number (NPWP) card; Special power of attorney if appointing another person to administer a Value Added Tax Free Certificate; Sea Transportation Company Business License (SIUPAL); Detailed description in accordance with the technical specifications of the Ship; and Grosse Ship Deed. In addition, other new SKB provisions must be paid if the import / acquisition of ships that have obtained the SKB facility turns out to be sold before 5 years from the date of purchase, plus $2 \%$ administration sanski per month. Input Tax on import and / or acquisition that is used to produce Ships which is free of imposed VAT, cannot be credited.

Provisions to apply for a SKB of a significant change where previously to get a VAT facility is enough to simply stamp the "government borne" stamp on each tax invoice, with this provision, National Shipping must have a VAT Examption Certificate (SKB) before receiving an incentive facility PPN.

c. VAT is not Collected (SKTD PPN)

In 2015, through Government Regulation 69 of 2015 and PMK 193 / PMK.04 / 20015, the government issued a new policy back in which to get taxation facilities in the form of VAT incentives that were originally released VAT, become VAT-Free, National Shipping must have a VAT Registration Letter No Collected (Certificate of No Collected) from the tax office where National Shipping is registered by attaching an Import and Acquisition Needs Plan (RKIP) that is not regulated in the previous incentive facility (SKB). In addition, National Shipping that submits SKTD by attaching RKIP must report quarterly realization of RKIP to the tax office. This new policy adds to the administrative burden for both National Shipping Companies and the Directorate General of Taxes. The very basic thing of this policy is the input tax paid for the acquisition of Taxable Goods and / or the acquisition of Taxable Services for which delivery is not collected Value Added Tax can be credited, which is in accordance with the neutral VAT characteristics.

VAT is an indirect tax that is imposed on the consumption of goods and / or services. Although the imposition can be done at each supply chain in the production, distribution and marketing of goods and / or services, the real VAT guarantor is the final consumer of the said goods and / or services. The imposition of VAT carried out on each supply chain in the production, distribution and marketing of goods and / or services is basically just a mechanism, which is to maintain its neutrality, on the VAT paid or collected in the links before the goods and / or services reaching end customers are set-off (credited). In other words, the set-off is a mechanism to maintain the neutrality of VAT along the production, distribution and marketing lines of goods and / or services subject to VAT so that there is no double taxation economically. With this mechanism, only the final consumer will really bear the VAT owed for the consumption of goods and / or services. 


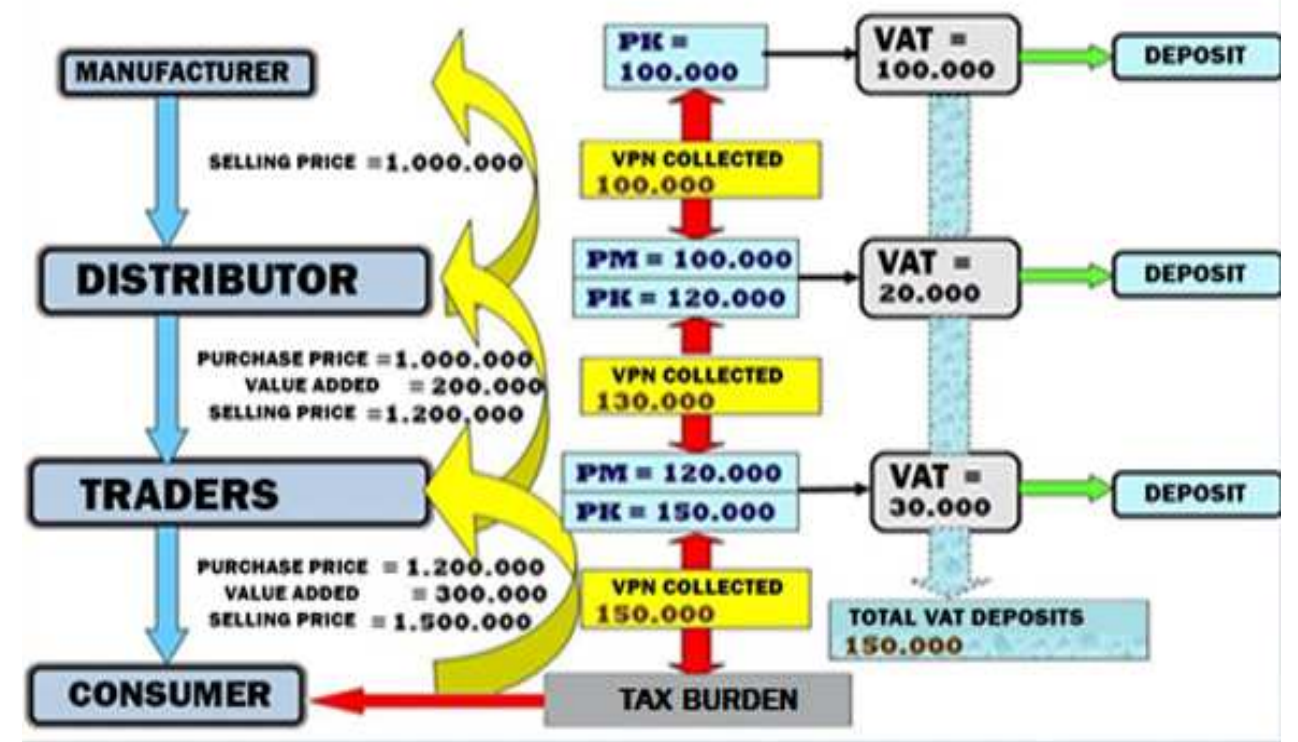

Fig.2 [11] VAT implementation in any chain

As is commonly applied in many countries that adopt a VAT system, all goods and / or services are basically Taxable Goods and / or Taxable Services. However, certain types of goods and / or services are exempt from the imposition of VAT by providing treatment exempt from the imposition of VAT or not subject to VAT (exemption) or subject to VAT at the rate of $0 \%$ (zero rating). Treatment is exempt from the imposition of VAT or not subject to VAT (exemption) usually given limited to the delivery of certain goods and / or services, while the imposition of VAT at $0 \%$ rate is usually given for the export of goods and for the export of several types of services. follows:

The principles of a good tax collection system by Rosdiana and Irianto are explained as

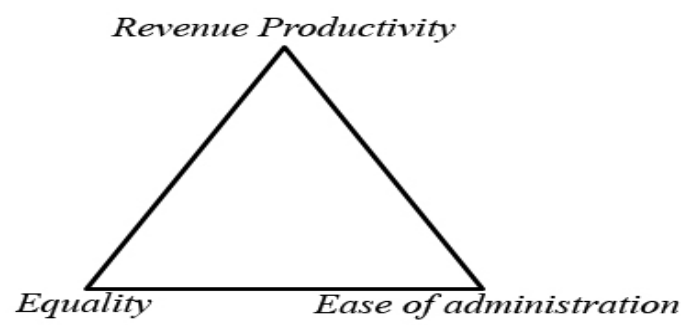

Fig.3. [7] The principles of an ideal tax collection system

a. Equity / Equality

A taxation system can be successful if the community believes that the taxes levied by the government have been imposed fairly and everyone pays according to their share. 


\section{b. Revenue Productivity}

Revenue productivity principle is a principle that is more concerned with the interests of the government, so this principle is often considered by the government as the most important principle. This principle is closely related to the function of tax as a source of state finance.

Taxes are actually the soul of the state, because without taxes, the state will not or have difficulty living, unless the country has income from natural resources (oil, gas, gold mines, iron ore, magnesium, etc.) and or from trade or industries. So, taxes are essentially about economic life of the country, not human life. The state's needs are the survival of its institutions, which are capable of carrying out their respective functions, other than physical human needs. Taxes are the country's main source of income besides natural resources [12]. Taxes are the main source of revenue, so in collecting taxes, it is also necessary to pay attention to the adequacy factor, so that the state is not arbitrary just to pursue the tax revenue target.

A tax levied for revenue is worthwhile only if it can generate meaningful revenue at socially acceptable rates. Some taxes may be levied for reasons other than revenue - punatively high rates to stop an undesirable activity or taxes applied simply to keep track of a particular activity-but revenue is the prime objective of most taxes [13].

Taxes for revenue purposes must be within reasonable limits acceptable to the public. Taxes are sometimes intended not for the purpose of state revenue but to limit or inhibit an activity which is detrimental to society by imposing high tax rates. Revenue is still the main objective of tax collection.

\section{c. Ease of Administration}

Ease of administration consists of 4 (four) principles, namely:

1) Certainty, in certainty principle states that there must be certainty, both for tax officials and all taxpayers and the whole community. The principle of certainty among other objects, subjects, taxes imposed, the basis for the imposition of tax rates, and procedures for fulfilling payment obligations and reporting - and the implementation of rights.

Without clear procedures, taxpayers will find it difficult to carry out their obligations and rights, and for tax authorities it will be difficult to oversee the implementation of tax obligations carried out by taxpayers also in serving the rights of taxpayers [14].

The procedure for obtaining VAT incentives for vessel purchases by national shipping companies has begun to be put in place by the Government for the first time, through Minister of Finance Decree No. 326/1996 in the form of VAT borne by the Government and the National Shipping Company that imports the vessel is only affixed with a "VAT under Government responsibility" stamp on each Tax Invoice or PIUD (import notification for use). In 2001, the procedure for obtaining VAT incentives for ship purchases by the National Shipping Company through Minister of Finance Decree No. 10/2001 changed KMK No. 326/1996 and requires the National Shipping Company to have a VAT Examption certificate (SKB) for every time that Import is issued by the Tax Office by first submitting an application to the Tax Office where the National Shipping Company is registered. From 2015 to the present, the procedure for obtaining VAT incentives for ship purchases by the National Shipping Company was changed again through Regulation of the Minister of Finance No.193 / 2015 and requires having an Uncollected Certificate (SKTD) attached to the Import and Acquisition Needs Plan (RKIP) submitted to the tax office at the beginning of the year, then every three months 
the National Shipping Company is required to report the realization of the RKIP to the Tax office. This provision does not only burden the tax administration of shipping companies but also the government, as stated by the General Chair of INSA.

2) Convinience, stating that when paying taxes it should be possible at a time that is fun /facilitating the Taxpayer, for example when receiving income. The provision of VAT incentives to shipping companies must be based on the principle of convenience. As for the pleasant moment for the shipping company is when doing the purchase of the ship by the shipping company with a procedure that is easy and straightforward. The current provision of granting VAT incentives for vessel purchases by Shipping Companies is felt to be increasingly difficult and complicated.

3) Efficiency, states that when a tax payment is said to be efficient if the costs incurred by taxpayers in paying their tax obligations are relatively lower or there are no additional costs incurred by taxpayers to pay their tax obligations. Efficient if the taxpayer does not need to pay additional costs to pay taxes (fiscal cost), the time required to pay taxes is relatively short (time cost), and no psychological costs are found in paying the tax due (psychological cost). The implementation of the granting of VAT incentives on vessel purchases by national shipping companies, can now be declared not yet fully efficient, because it still raises fiscal costs, including the need for a division that handles the handling of VAT incentives, transportation costs in handling requests for VAT incentives, there are still time costs, among other things, time needed to fill out the VAT incentive request form, the time needed to ensure the purchase of the ship with management, the time needed to report the realization of the purchase of the ship, as well as the presence of physical costs, including stress, uncertainty - the potential for the approved VAT incentive can be canceled, so the facilities that have been enjoyed must be paid off.

4) Simplicity (simple), This principle states that in compiling tax regulations as well as taxation policies and tax administration, it must be made simple, easy to implement and not convoluted. At present, the administration of taxation in obtaining VAT incentives for vessel purchases is not simple. National Shipping Companies that will receive PPN incentives must submit an application for a Certificate of Uncollected (SKTD) by attaching a plan for vessel purchase requirements (RKIP) and report the realization of the RKIP every three months to the tax office.

\section{Conclusion}

Based on this research, the VAT incentive policy in the shipping industry in the purchase of ships both imported and domestic purchases which was originally DTP, was freed to be collected is not in accordance with the characteristics of VAT which are Neutral in nature, where the input tax paid for the acquisition of Taxable Goods and / or acquisition Taxable services for which delivery is not collected Value Added Tax can be credited (sett-off) as a mechanism for maintaining neutrality in VAT. It's just that the PPN incentive administration policy for the purchase of ships that burden national shipping and government (DGT) needs to be reconstructed in accordance with the principle of ease of administration. First, Certainty, the procedure for obtaining VAT incentives on vessel purchases must be able to provide certainty for national shipping companies. Considering 
the procedure of obtaining VAT Incentives since it was implemented in 1996 until now, it has experienced three changes. Ideally, regulations are recommended not to change very often, especially in tax administration. Secondly, Convenience, the provision of VAT incentives on vessel purchases should be done at an enjoyable time, namely when purchasing vessels both imported and domestic. Third, efficiency, by maximizing information technology to eliminate fiscal cost, time cost and psychological cost, last or fourth, Simplicity absolutely makes tax administration simple and easy to do by maximizing information technology / digitalization.

The reconstruction of the VAT incentive administration policy for the purchase of ships to the National Shipping Company which is currently in effect is absolutely necessary, based on the principle of ease of administration by maximizing information technology (digitization), so that the taxation policy is expected to be able to develop the growth of the National Shipping Industry.

\section{References}

[1] Saragih, B. T.National Shipping Empowerment. Panel Discussion Material and KADIN Maritime Workshop (2003)

[2] Team, M. The Cabotage Principle and the Nusantara Maritime Industry. Retrieved from Nusantara Maritime News: https://maritimenews.id (2015, August 12)

[3] Book I Transportation Statistics, Ministry of Transportation - RI (2018)

[4] DetikNews.ID. Sea Toll Road Transportation Industry Improves Regional Economy. Retrieved from Detiknews.ID: https://detiknews.id (2019, February 4)

[5] Supriyanto. National Shipping Dynamics and Challenges. ICE - BSD Conference (p. 21). Serpong: INSA (2017)

[6] Spitz, B. International Tax Planning. London (1972)

[7] Rosdiana, H., \& Irianto, S. E. Introduction to Tax Science: Policy and Implementation in Indonesia. Jakarta: Rajawali Press (2014)

[8] Cresswell, J. W. Research Design: Qualitative and Quantitative Approach. London: Sage Publication Inc (1994)

[9] Basrowi \& Suswandi. Understanding Qualitative Research. Jakarta: Rineka Cipta (2008)

[10] Moleong, L. J. Revised edition of the Qualitative Research Methodology. Bandung: PT Remaja Rosdakarya (2006).

[11] Academic paper on Value Added Tax law (2016)

[12] Soemitro, R. Principle and Taxation I. Bandung: Refika Aditama (1998)

[13] Mikessel, J. L. Fiscal Adminitration, Analysis and Application for Public Sector. Illionis: The Dorsey Press (1982)

[14] Rosdiana, H., \& Irianto, S. E. Introduction to Tax Science: Policy and Implementation in Indonesia. Jakarta: Rajawali Press (2014)

[15] Law No. 11 of 1994 concerning Amendments to Law No.8 of 1983 concerning Value Added Tax of Goods and Services and Sales Tax on Luxury Goods

[16] Law No. 18 of 2000 concerning the Second Amendment to Law No.8 of 1983 concerning Value Added Tax of Goods and Services and Sales Tax on Luxury Goods

[17] Law No. 42 of 2009 concerning the third amendment to Law No.8 of 1983 concerning Value Added Tax on Goods and Services and Sales Tax on Luxury Goods

[18] Presidential Decree No. 4 of 1996 concerning Amendments to Presidential Decree Number 18 of 1986 concerning Value Added Tax payable on imports and delivery of certain taxable goods and 
taxable services borne by the Government as amended several times, the latest by Presidential Decree Number 42 of 1995

[19] Government Regulation No. 146 of 2000 concerning the Import and or Delivery of Certain Taxable Goods and or the Delivery of Certain Taxable Services that are Exempt from the Imposition of Value Added Tax

[20] Government Regulation Number 69 Year 2015 concerning the Import and Delivery of certain means of transportation and the delivery of certain taxable services related to certain means of transportation which are not subject to Value Added Tax

[21] Minister of Finance Decree No. 326 / KMK.04 / 1996 concerning Procedures for Providing Value Added Tax Facilities Borne by the Government on Ship Imports, Ship Handover, Ship Rental Services, Ship Agency Services, Ship Maintenance / Repair Services, and Port Services

[22] Decree of the Minister of Finance No.10 / KMK.04 / 2001 concerning the Granting and Administration of Value Added Taxes Exempted from Importing or Or Handling of Certain Taxable Goods and or Handling of Certain Taxable Services

[23] Minister of Finance Regulation No. 193 / PMK.03 / 2015 concerning Procedures for the Provision of Value Added Taxes on the Import and delivery of certain transportation equipment and delivery of certain taxable services 